Title

An ideology critique of the use-value of mathematics Journal

Educational Studies in Mathematics

Volume 84, Issue 1, pp 15-34

Cover Date

2013-09-01

DOI

$10.1007 / \mathrm{s} 10649-013-9484-4$

Print ISSN

0013-1954

Online ISSN

$1573-0816$

Publisher

Springer Netherlands 


\title{
AN IDEOLOGY CRITIQUE OF THE USE-VALUE OF MATHEMATICS
}

\author{
Alexandre Pais \\ Department of Learning and Philosophy \\ Aalborg University \\ Sohngårdsholmsvej 2, 9000 Aalborg, Denmark \\ xande@,learning.aau.dk
}

The idea that mathematics is needed for our mundane everyday activities has raised the question of how people deal with mathematics outside the school walls. Much has been written in mathematics education research about the possibility of transferring knowledge from and into school. Whereas the majority of this literature commends the possibility of transfer, thus assuming both the desirability of transfer and the importance of school mathematics for the professional and mundane lives of individuals, I am interested in developing an ideology critique on the beliefs underpinning the research on this issue. It will be argued that the use-value attributed to school mathematics disavows its value as part of a political and economic structure, which requires school mathematics to perform other roles than the one related with utility. This critique will be illustrated through the exploration of a typical transfer situation between school and workplace.

Keywords: Economy, ideology, transfer, use-value, Lacan, Žižek

\section{Introduction}

As researchers engaged in making mathematics more meaningful and pleasurable we tend to pass over questions whose answers are normally taken for granted. One of these questions is quite an elementary one: why is (school) mathematics important? The reasons may vary depending on one's area of research. For some researchers mathematics is important because it contributes to the development of higher psychological functions: logical thinking, abstraction, metacognition, or creativity (e.g. Stech, 2008). For others the importance of learning mathematics has more to do with the acquisition of mathematical instruments for solving everyday problems (e.g. de Lange, 1996), whereas others privilege a hedonistic dimension, by emphasizing how aesthetic, pleasurable and 
attractive the learning of mathematics can be (e.g. Boaler, 2009). More recently, an emphasis on the cultural importance of mathematics has been growing, with researchers stressing the range of possibilities that mathematics offers to live it as a social, historical and cultural experience (e.g. Radford, 2012). On a more critical note, some researchers emphasize how powerful mathematics can be in formatting reality, which requires an exploration of real mathematical models in a critical way (e.g. Skovsmose, 1994). Although these five areas of importance can be categorized into more nuanced goals of mathematics teaching (see Niss, 2007; Bishop \& Forgasz, 2007), we can see how the importance of mathematics is invariably located in the immediate properties of mathematics. That is, the reasons invoked to justify the importance of mathematics in schools are conceived in terms of its inherent characteristics, whether they are related to the development of mental functions, the utility of this school subject for people's lives, its beauty, cultural richness, or the ideals of citizenship. Mathematics seems to embody the right properties that make it important.

Yet what if we conceive the importance of mathematics not in terms of mathematics itself but in terms of the place this subject occupies within a given structural arrangement? That is, could it be that mathematics is important not because of its characteristics-problem-solving, utility, beauty, cultural possibilities, etc.- but because of the sociopolitical importance assigned to it? The underlying aim of this article is to probe the way in which researchers conceive the importance of mathematics. The fields of ethnomathematics, critical mathematics education and, more generally, what has been known as the social, cultural and political perspectives in mathematics education have shown how mathematics is involved in processes of credibilization and social selection (Atweh, Forgasz, \& Nebres, 2001; Bishop \& Forgasz, 2007; Stinson, 2004), in excluding groups of people considered to be disadvantaged (Martin, 2011; Secada, Fennema, \& Byrd, 1995), in providing a clear social mechanism of accountability (Brown, 2011), or in fostering the appropriation of behaviours and modes of thinking and acting that make every child governable (Popkewitz, 2004). These studies compel us to think about the importance of mathematics not in terms of object mathematics — as valuable knowledge and competence — but in terms of the role it plays and its attendant submissions to political as well as economic criteria and goals. However, I challenge the reader to find a piece of research or a national curriculum where the importance of school mathematics is articulated not in terms of its direct characteristics but in terms of the value it has within the complex universe of socioeconomic relations, a document saying, for example: "mathematics is important because it allows students to accumulate school credit and achieve higher social positions"; or "mathematics is important because it gives credibility to the course"; or 
even "mathematics is important because it allows reproduction of social inequalities". Apparently, people know this is the case. Nonetheless, it is never stated explicitly in public discourse. "Officially," the importance of mathematics is stated in terms of knowledge and competence.

It seems that we are dealing here with two different logics of importance. On the one hand, there is the importance deriving from the position mathematics occupies as a school subject involved in mechanisms of accreditation, social exclusion, and the like. This importance is seen as extrinsic to mathematics, resulting from the social role it is asked to perform. On the other hand, there is the importance of mathematics in itself, that is, as a key knowledge and competence for developing the student's personality and citizenship, as well as encouraging societal and technological progress. How should we articulate these two logics? One way is to oppose them, to conceive the role assigned to mathematics by broader politics as a corrupting force of the importance it has for individual and societal development. As a consequence, the more mathematics is involved in ad hoc social and political processes, the more researchers should be concerned about highlighting its intrinsic qualities. But what if these two logics are not opposite but complementary? That is, what if the discourse around the intrinsic importance of mathematics provides the ideology necessary for masking the political and economic importance of mathematics? This was the main conclusion drawn by Sverker Lundin (2012) after analysing how "word problems" are researched in mathematics education. Lundin concluded that the usefulness of mathematics for solving real-life problems is not a consequence of any direct properties of this science, but results from the workings of mathematics education itself. Moreover, the symbolic discourse around the importance of mathematics for everyday activities conceals the real importance of mathematics as a testing and grading device. What is seen as a direct property of object mathematics - its utility - is indeed the result of the place mathematics occupies within the structure of capitalist economics.

In this article I also treat the discourse around the utility of mathematics as a symptomatic case of an ideology set on effacing the role which school mathematics plays in political economy. By standing a certain distance from the fantasy (Žižek, 2008b) that extols the importance of mathematics as use-value (Dowling, 1998) — the utility of mathematics in optimizing the mundane activities of people_- by refusing to stage it directly, I intend to point to the system's own contradiction, to show that this fantasy is no more than the result of the activity of all of those who believe in it (Lundin, 2012). It is a pure fiction that simultaneously conceals its own inconsistency and allows it to endure. It will be argued that such fiction provides an ideological screen against the role school mathematics plays within the socioeconomic organization of schooling. 
I will start by discussing the importance of considering the field of economy and the concept of ideology when reflecting on mathematics education as a field of research. Both economy and ideology have been disappearing from academic discourse, giving rise to new ways of mapping the Political generally associated with the postmodern trend. As argued by Eagleton (2001), postmodern theorists tend to see ideology as teleological, "totalitarian" and metaphysically grounded and, as such, not useful for analysing the contingent and plural world in which we live today. Grossly travestied in this way, the concept of ideology has been cutting itself off from research in social sciences (Eagleton, 2001; Jameson, 1991; Vighi \& Feldner, 2007; Žižek, 2008a), and economy has been relegated to one among many influential principles of society (Žižek, 2012; Brown, 1995). The disavowal of these old Marxist categories is particularly evident in the sociopolitical turn in mathematics education (Gutiérrez, 2010; Valero, 2004). By reducing the Political to identity and power issues-what is called (Butler, Laclau, \& Žižek, 2000, p. 202) "issue-oriented politics"- sociopolitical studies leaves us without theoretical tools to address the global economic system of capitalism and the role of school mathematics within it. Afterwards I review problems with the research on the use-value of mathematics, particularly the research done on the issue of transfer. My aim is to evidence the difficulties or even the impossibility of transfer; and to analyse how research conveys an ideology that forecloses such difficulties for the sake of school mathematics.

The second part of the article will deal with the exploration of a typical transfer situation between school and workplace: young students attending a blacksmithing course with mathematics as a compulsory subject designed to be useful for their practice. I will draw on the research developed by Elsa Fernandes (2004, 2008), who worked closely with the participants in this study during her $\mathrm{PhD}$ dissertation. As we shall see, although the course is designed so that students can learn meaningful mathematics for their work, what they end up learning is that in order to pass the course they have to pass mathematics which, although useless, is presented as an indispensable qualification for a blacksmith. That is, they learn how to engage in a discourse without really believing in it. Moreover, they learn that in order to pass the course this facade must be maintained. Such incongruence between what people say and what people do is in line with Žižek's (2008a, 2008 b) theorization, the mode of ideology at work in contemporary society.

\section{Economy, ideology and the importance of researching research}


The need to understand how broader ideologies and structures impact on what is happening in classrooms has been observed by some researchers (e.g. Brown, 2011; Gutiérrez, 2010; Radford, 2012; Valero, 2004), and is one of the main motives for the sociopolitical turn in mathematics education (Gutiérrez, 2010; Valero, 2004). One of the obstacles to situating mathematics in the Political is related to the closure of the object of research to the learning of mathematics (Pais \& Valero, 2012). Another has to do with the kind of theories used in the field, which has been historically grounded in mathematics and psychology (Brown, 2011; Sierpinska \& Kilpatrick, 1998; Valero, 2004). Acknowledging these obstacles, researchers have been bringing into the field contemporary theories that, although not immediately related either to "mathematics" or "learning", have the potential to enable alternative understandings not only of the teaching and learning processes, but also of mathematics education as a field of research (Brown \& Walshaw, 2012).

Among contemporary theory, the philosophy of Slavoj Žižek and Lacanian psychoanalysis have been used in mathematics education to situate the problems that students and teachers experience in their daily school lives not only at a "mathematical" or "psychological" level but at a level where broader social systems can be taken into consideration (Brown, 2008; Walshaw, 2004). Furthermore, they have also been used by researchers to develop a sociopolitical critique of the way in which research assigns importance to mathematics as a school subject, thus contributing to the reflexivity of research on its discourses and effects (Baldino \& Cabral, 2006; Lundin, 2012; Pais, 2011a; Pais \& Valero, 2012). This exercise in "researching research" (Pais \& Valero, 2012) is important since many of the problems related to school mathematics cannot be fully conceptualized without some kind of "political mapping" that situates them not at the level of "learning" or "mathematics" but as part of the political and economic landscape of our times (Brown, 2011; Pais \& Valero, 2012). Lacanian psychoanalysis and Žižek's philosophy have offered researchers theoretical tools not only to renew mathematics education in itself - better classroom practices, different understandings of what mathematics is and how it can be taught and learned — but also for itself, that is, to renew the way in which researchers see the importance of this school subject and the role of research.

Sociopolitical studies in mathematics education have "politicized" a series of domains previously considered "apolitical” (Gutiérrez, 2010; Lerman, 2000; Valero, 2004). As I explore elsewhere (Pais \& Valero, 2012; and also Lundin, 2012; Klette, 2004), however, notwithstanding the receptiveness of the field to methodologies and theories that place mathematics education in relation to social, cultural and political dynamics, the fact remains that solutions to the problems of 
practice continue to be thought of in terms of practice alone. Just like the strictly "psychological" approach to mathematics education, within the sociopolitical turn also the possibility of calling into question the structure of discourse orienting research practice is foreclosed. This happens because the notion of the "political" within which a sociopolitical perspective operates is grounded in the depoliticization of research and political economy (Pais \& Valero, 2012).

How do sociopolitical approaches disavow the political economy? Such approaches tend to move from Marxist views of society, where structures are conceived as determining individual agency, to critical and poststructuralist approaches where the focus is on identity and power issues (Gutiérrez, 2010; Valero \& Stentoft, 2010). Therefore, a shift has occurred "from examining school structures and institutions to examining discourses and social interactions" (Gutiérrez, 2010, p. 3), and "educators who take a socio-political perspective stance recognize that mathematics education is identity work" (p. 17), engaged in transforming mathematics education in ways that privilege more socially just practices regarding marginalized students. This turn is in line with postmodern educational discourses which conceive change not as a change in the totality - a change in the global mode of production, for instance - but as being based on local struggles which take into account the complexities of particular contexts (Cole, 2003; Peters \& Burbules, 2004). As I explore elsewhere (Pais, 2011b, 2012), by emphasizing issues of power and identity, these theories disavow a broader comprehension of schools as places of economic production. Hence, within the sociopolitical turn, the problem of failure in school mathematics is understood as having to do with the particularities of specific groups of students considered to be at a disadvantage (Gutiérrez, 2010; Sriraman, Roscoe, \& English, 2010) and not so much as an all-encompassing reality permeating the whole of schooling, thus affecting all students. The strategies for bypassing failure are thus orchestrated in terms of developing better classroom strategies in order to guarantee a successful mathematics education for all, according to students' own particular identities.

The idea of a central organizing principle is rejected by postmodern theorists (Lyotard, 1984; Seidman, 1994). Instead, they emphasize a multitude of organizing principles, what Wendy Brown (1995) refers to as the postmodern mantra "race, class, gender, sexuality" (p. 61). This debate, opposing the Marxian primacy of political economy and what is usually called identity politics ${ }^{1}$ is becoming a central one in contemporary theory. Whereas authors such as Laclau or Butler (Butler et al., 2000) argue that economy (particularly the notion of class) is just one type of identity politics,

\footnotetext{
${ }^{1}$ But also politics of recognition (Butler et al., 2000), or politics of difference (Seidman, 1994). For an account of the terms in which this discussion is carried out see, for example, Butler et al. (2000), Eagleton (2001) and Vighi and Feldner (2007); and within education Cole (2003).
} 
and one which is becoming less and less important in the world today, Žižek (2008a) and Jameson (1991), in accordance with Marx, defend the opposite: economy qua structuring principle of the social totality colours all other particular struggles. Making use of Hegel's dialectics, Žižek (2004) describes this overdetermination carried out by capitalism as follows: "[m]ore than ever, capital is the 'concrete universal' of our historical epoch. What it means is that while it remains a particular formation, it overdetermines all alternative formations, as well as all noneconomic strata of social life" (p. 185). This is not to say that everything should be reduced to economy, thus constituting a vulgar Marxism. The "economic" does not stand for the entirety of social reality but is instead a particular element that, by being repressed, ends up determining the sphere of the Political. ${ }^{2}$

Within the Lacan-Žižek axis, the status of the "repressed" is not one of being outside the symbolic field of meaning. Rather, it is because it is repressed that it functions as the determining element of the symbolic tissue. Within current politics, economy is not simply excluded, naturalized, by an ideological formation, but stands for the necessary lack around which ideology is itself articulated. Except for the work of Roberto Baldino and Tânia Cabral (Baldino, 1998a, 1998b; Baldino \& Cabral, 1998, 1999, 2006), and, more recently, Julian Williams (2011), Brown and McNamara (2011), and myself (Pais, 2012), there has been no attempt to theorize the economic dimension of school mathematics. These authors are not considered to be part of the sociopolitical turn (Gutiérrez, 2010; Valero, 2004), where emphasis is given to identity politics. Despite the diversity of studies within the sociopolitical turn, what is common to them is a disavowal of the economic. ${ }^{3}$

Central to an economic conceptualization of school mathematics is the idea that the value of mathematics is not inherent to mathematics, but a result of the formal place mathematics occupies

\footnotetext{
2 The process of "forgetting" the economic cause has been a major feature not only of the postmodern trend but also of what Ozselçuk and Madra (2010) call "the humanist Marxism", expressed in the work of well-known Marxists of the twentieth century such as Adorno, Lukács and, more recently, Habermas and Lyotard. These works read Marx in ways that contain or even annul the constitutive determinacy of economy. In the case of postmodernism, the Marxist primacy of the economic is watered down into a set of political, cultural and sexual impediments. In the case of so-called postMarxists, what is in fact a structural problem, endemic to a mode of production, is transformed into an abstract problem of greed, which could be solved by increasing the values of solidarity, trust, sharing and general commitment to improving the quality of human life (Ozselçuk \& Madra, 2010). Painted in this way, Marxism has an uncanny resemblance to a catechism, with charity as the main safeguard of humankind. Economic exploitation, the foundation of capitalism, is reduced to political domination, which can be solved through the goodwill of engaged people.

${ }^{3}$ This is also the case with the vast majority of mathematics education research (which not only disavows the economic but also shows a historical tendency to disavow the social and cultural dimensions, by being centred in a psychological approach). As Paola Valero and I found (Pais \& Valero, 2012), even socioculturalism and its use of Marxist psychological theories such as those of Lev Vygotsky and Alexei Leontiev, end up focusing on the cultural and historical dimension of learning, thus completely obliterating its economic dimension. Nonetheless my criticism here concerns research that, although seeking to go beyond a "didactical", "psychological" and "sociocultural" perspective of school mathematics, by means of emphasizing "political" issues, refrains from analysing the relation between school mathematics and the capitalist system.
} 
within late capitalism. School mathematics is part of what Vinner $(1997,2000)$ called the school's credit system, which has less to do with knowledge and competences than with selection and accreditation:

I suggest that the students have very good reasons to study mathematics. It is not the necessity of mathematics in their future professional life or their everyday life. It is because of the selection role of mathematics has in all stages of our educational system. (Vinner, 2000, p. 2)

Contrary to the assumption that mathematics empowers people because it provides them with some kind of knowledge or competence, Vinner suggests that this empowerment has instead to be understood in the field of value. Mathematics allows students to accumulate credit in the school system that will allow them to continue studying and later to achieve a place in the sun. In this (economic) perspective, mathematics empowers people not so much because it provides some kind of knowledge or competence to them but because it is posited as an economically valuable resource. Accepting this condition, Baldino (1998a, 1998b) uses the Marxian categories of use-value, exchange-value and surplus-value - the credentials which represent the surplus products of learning - to show how in schools students learn, above all, to participate in and accept the conditions of production and seizure of surplus-value. The value of the ones who fail is appropriated by the ones who pass as surplus-value. Failure is posited as a necessary condition for schooling: "in order to perpetuate the process of production/seizure of surplus value, a certain amount of failure is necessary" (Baldino, 1998a, p. 5). Therefore, "failure of students means success of the institution" (Baldino \& Cabral, 2006, p. 34). It is my contention that failure in achieving a meaningful mathematics education is not a malfunction which could be solved through better research and a proper crew, but is endemic in capitalist schooling (Pais, 2011b, 2012).

To acknowledge that failure is a necessity of current schooling is not easy. Somehow, one needs to believe that the goals for which we all strive are equity, social justice, inclusion and the like. We need to believe that the presupposition of the system is a "good" one, so that we can accept the unequal reality in which we live. In the Lacan-Žižek axis, ideology is conceived as a defence against some traumatic real, a "fantasy-screen" (Žižek, 2008b, p. 7) focused on restoring order to a situation that otherwise seems chaotic or impossible. Mathematics education research partakes in an ideology set on avoiding the necessity of failure within current schooling (Pais, 2011a, 2011b, 2012; Pais, Fernandes, Matos, \& Alves, 2012). A fantasy provides a rationale for failure. When confronted with the worldwide problem of failure in school mathematics and the societal demand 
for "mathematics for all", ${ }_{4}^{4}$ research establishes an explanatory scheme within which an approach to the problem is proposed. Although the particular constellation of the fantasy narrative changes from one research trend to another-as I mentioned in the introduction, there are different ways of arguing for the importance of mathematics - the figure of "mathematics" functions as that which simultaneously thwarts the realization of the ideal goal of a universally meaningful mathematics and compels the articulation of an entire discourse concealing the necessity of failure (hence providing researchers a frame within which to develop their work).

Ideology can thus be conceptualized as a "totality set in effacing the traces of its own impossibility" (Žižek, 2008a, p. 50); and an ideology critique seeks not to show "how things really are" but rather to pinpoint what in the midst of a symbolic edifice stands for the specific exclusion, the pertinent lack. An ideology critique as described by Žižek is not so much about exposing what Engels (1968) called the "false consciousness"-where ideology is perceived as an "illusion", as a mistaken, distorted representation of its social content - and goes further than Althusser's material existence of ideology (1994), where an "external" ritual performatively generates its own ideological foundation (the case of Althusser's famous Ideological State Apparatuses). Whereas traditional ideology critique seeks to unravel the particular interests behind a given ideological statement by analysing its inconsistencies in order to pierce the actual mode of its functioning, it does so in an ineffective way since - and this is the main contribution of Žižek to ideology critique -it neglects the relation of ideology with what Lacan (2007) called jouissance or, in its anglicized form, enjoyment. Every ideology attaches itself to some kernel of jouissance which, however, retains the status of an ambiguous excess (Žižek, 2008b, p. 63). What the spectre of ideology conceals is not reality but its "repressed", the "irrepresentable X on whose 'repression' reality itself is founded" (Žižek, 1994, p. 20). What we usually call ideology—the "hidden" agenda that reduces school mathematics to a mechanism of accountability and credit—is not "ideological" but real in the precise Lacanian sense: something that remains unchanged notwithstanding our awareness of it. ${ }^{5}$ In our case, the real is the worldwide school accreditation system that is indifferent to the didactical,

\footnotetext{
${ }^{4}$ A slogan propagated in the last decades by professional organizations (e.g. NCTM, 2000) and researchers (e.g. Presmeg, 2010) alike.

${ }^{5}$ When Lacan (seminar of 23 April 1974, in Le séminaire, Livre XXI: Les non-dupes errant, unpublished, cited in Fink, 1995, p. 142) says that "[t]he real is what does not depend on my idea of it", he is pointing to the dimension of human subjectivity that is independent of our knowledge of it - the Freudian unconscious. Such a conceptualization is what allows Žižek to transpose the real qua psychic dimension to social analysis. His argument is that we may very well know that our economic system is unfair, that schools are subjected to economic pressures, but nonetheless its functioning is real, i.e. it does not depend on our knowledge of it. The same point is made by Lundin (2012) apropos of mathematics education: "[m] easurements, grades, and examinations have consequences only inside the system in which they play a central role (...) it should be as obvious that opinions, thoughts and feelings towards this system do not affect its proper functioning" (p. 83).
} 
curricular and even cultural innovations perpetrated by researchers, governors and practitioners. What is usually seen as "ideological" is indeed the real of schooling. This repressed real, which stands for the economy of schooling, is simultaneously what is excluded from research and what gives consistency to this same research. This determination is not exerted from outside, but is a result of people's own action. It is a clear indication of the material force of ideology which makes us reject what we see and know. This happens because for some reason we enjoy not believing in what we know. My argumentation intends to show that what we enjoy that hinders us from acting according to what we know is precisely the repressed economic core of schooling. By being repressed, the economic accounts for its efficiency. It functions as the "concrete universal" determining the relation of the subject with the real of its jouissance.

\section{The impossibility of transfer and the role of ideology}

The importance attributed to the use-value of mathematics is widespread both in research and in curriculum-making. The importance of exploring "real-life" situations with students is associated with a more meaningful learning of mathematics, the development of competent citizens, the enhancement of general problem-solving competencies and attitudes, and the use of mathematics in solving problems of everyday life (e.g. Boaler, 1993; Brenner, 1998; Chapman, 2006; de Lange, 1996; Frankenstein, 1983; Freudenthal, 1973; Gravemeijer, 1994; Niss, Blum \& Huntley, 1991; Skovsmose, 1994). In this realistic perspective, the importance of mathematics comes not so much from its "internal" characteristics (as was the case with the new math movement), but from the possibility mathematics offers for people to understand and act within real-world situations. This view has influenced curricular changes all around the world (Blum \& Niss, 1991; de Lange, 1996; Dowling, 1998), which can easily be seen in the curriculum guidelines from countries as disparate as Colombia, Portugal, South Africa and New Zealand. Evaluations of what is considered to be a quality mathematics education seriously take into account the capacity of students to use mathematics as workers and citizens (Atweh, Graven, Secada, \& Valero, 2011; Bishop \& Forgasz, 2007). A global assessment programme known as PISA (OECD, 1999) has been implemented in the principal industrialized countries, based on the idea that students should be proficient not merely in terms of mastering the school curriculum but in terms of the important knowledge and skills needed in adult life. In research, curriculum-making and evaluation, the importance of mathematics for understanding and dealing with real situations — its use-value — has become a leading pillar of the learning of mathematics in schools. 
The belief that students should be able to apply school mathematics in real-life situations is supported by a considerable amount of research exploring the relation between school and out-ofschool mathematics; whether these are "crystallized" mathematics which the person needs to learn formally learn or "local" mathematics which need to be recognized and included within school mathematics. This brings up the issue of transfer: the use of ideas and knowledge learned in one situation in another (Evans, 1999). Traditional views of transfer that assume the continuity between school and out-of-school activities have given way to investigations which suppose the contextuality of mathematical reasoning, challenging the dominance of strictly cognitive perspectives in mathematics education (Abreu, Bishop, \& Presmeg, 2002; Boaler, 1993, 1999; Evans, 1999). Important studies have indicated that the mathematics used by children is quite different in and out of school, and that proficiency in everyday mathematics does not necessarily translate to a good performance in school mathematics (Abreu, 1995; Lave, 1988; Nunes, Schliemann, \& Carraher, 1993; Saxe, 1991). These studies have been particularly important in criticizing the idea that we can abstract from the context some "mathematical task" as if the mathematics involved were the same and thus capable of being transferred from one context to another without any kind of "misrecognition". If knowledge has no "essence" which can be transferred from one situation to another, that is, if knowledge is ultimately determined by the situation (Lave, 1988), then we will encounter problems when attempting to "harness" local knowledge in schools while at the same time maintaining its localized character. From the moment we bring the local into school, it becomes a "scholarized local", even if the problems addressed are out-of-school problems (Gerofsky, 2010; Lave \& McDermott, 2002; Pais, 2011a).

As a result, many critics have observed that the kind of realistic tasks promoted by formal education do not have a positive effect either in terms of mathematical learning or in the transference of knowledge to everyday situations (e.g. Boaler, 1999; Brenner, 1998; Evans, 1999; Verschaffel, Greer, \& De Corte, 2000; Williams \& Wake, 2007). As recently explored by Lundin (2012), this critique can take two different forms. The more common one targets the implementation of realistic tasks, contesting the lack of authenticity, fidelity and realism of the problems and situations worked with students (e.g. Boaler, 1999; Hoyles, Noss, Kent, \& Baker, 2010; Skovsmose, 1994; Verschaffel, Greer, Van Dooren, \& Mukhopadhyay, 2009; Williams \& Wake, 2007). The purpose of such an approach is to increase the similarity between everyday mathematics and school mathematics by studying under what circumstances everyday mathematics becomes meaningful in the classroom. On the other hand, and in a much smaller number, some 
researchers have argued that the problem is not one of implementation but one that is inherent in the very idea that mathematical knowledge is a useful tool for understanding and mastering the world outside school (Dowling, 1998; Gerofsky, 2010; Lundin, 2012; Pais, 2011a; Stech, 2008). Lundin (2012) suggests that the very idea of a simultaneous formation of competence to understand and master the world using mathematics and a perspective which shapes the world in a way that makes this competence relevant is peculiar to and characteristic of mathematics education research. His investigation bears witness to the fact that the importance of mathematics as use-value does not reside within object "mathematics" itself; it is, instead, the result of the subjective activity of all of those who assert its importance:

While mathematics may not be very useful as a means to understand and control the social and physical reality, the argument of this article shows that the very attempt to make it useful contributes in a fundamental way to the very constitution of the peculiarly modern reality in which we imagine such use to take place. (p. 11)

The fact that modernity sees mathematics in the world results not from the real features of the world itself but from the workings of modern institutions such as mathematics education. It is the suggestion itself that mathematics is important for mundane activities that makes us believe that mathematics is indeed important for such activities. ${ }^{6}$

Studies on the relation between school mathematics and the workplace (e.g. Hudson, 2008; Riall \& Burghes, 2000; Williams \& Wake, 2007), dealing with real-world problems (e.g. Boaler, 1998; Brenner, 1998; Jurdak, 2006) or within ethnomathematics (Pais, 2011a), often reach the conclusion that people do not use school mathematics in their daily lives. Rather, they develop their mathematical skills in situ, that is, in the specific place where it is needed. Recent studies within the framework of activity theory often reach the same conclusion: out of school mathematics has its own distinct genre, according to the local practice and its activity system, the instruments and division of labour and power, as well as the productive goal of the whole activity (Jurdak, 2006; Williams \& Wake, 2007). According to Ernest (2007), this happens because the mathematics behind our high-tech society is just a small part of the huge amount of research being done in

\footnotetext{
${ }^{6}$ At stake here is what in contemporary theory is called the performative power of the word (e.g. Butler, 1997; Derrida, 1976): reality as something which is constituted, posited by the subject. When we say that the world is written in mathematical language - the Galilean idea that mathematics is everywhere - we are not asserting some ontological truth about the world or about mathematics; rather, it is by means of our declaring it that the world becomes "written" in mathematics. The truth claim of a statement cannot be authorized by means of its inherent content, but results from the "'rationalization', the enumeration of a network of reasons, masking the unbearable fact that the Law is grounded only in its own act of enunciation” (Žižek, 2008b, p. 100).
} 
mathematics; some kind of applied mathematics that ends up being routinized and used in a "technical" way. This mathematics is learned by people in practice, outside school: "[i]t is not academic mathematics which underpins the information revolution. It is instead a collection of technical mathematised subjects and practices which are largely institutionalised and taught, or acquired in practice, outside of the academy" (p. 31).

However, and notwithstanding the evidence that people do not use or transfer school mathematics in the way desired by many researchers, the belief that students profit from being confronted with real-life situations endures as an important argument justifying the teaching and learning of mathematics in schools. As symptomatically suggested by Brenner (1998), “[a]lthough this paper has reported on the disjunction between everyday commonsense and school mathematics, this does not mean that practical knowledge should not or cannot serve as a basis for school learning" (p. 151). ${ }^{7}$ The problem, as I previously mentioned, is seen as a matter of (failed) implementation, which can be solved by means of infusing the curriculum with more open-ended problems (Brenner, 1998), exploring contexts that reflect realistic and complex workplace situations (Williams \& Wake, 2007), understanding classrooms as communities of practice (Boaler, 1999), improving teacher education (Chapman, 2006), refining the theoretical concepts used in research (Evans, 1999), and using authentic learning activities and interactive software design (Hoyles et al., 2010). In these studies the faith (Lundin, 2012, p. 8) ${ }^{8}$ involved in the importance given to the usevalue is exposed. When researchers are confronted with difficulties in transfer, they proceed by

\footnotetext{
${ }^{7}$ A remarkable example is given by Jurdak (2006). After concluding that "the activity of situated problem solving in the school context seems to be fundamentally different from decision-making in the real world because of the difference of the activity systems that govern them" (p. 296), and that students "define their own problems, operate under different constraints, and mathematics, if used at all, plays a minor role in their decision making" (p. 296), Jurdak still insists on the importance of confronting students with real-life situations: "simulations of such authentic real life situations as embedded in situated problem solving may provide a plausible option to develop appreciation of the role, power, and limitations of mathematics in real-world decision-making" (p. 296). He adds, "though quite different in real life from that in school, the process of mathematization is essentially the same and having experience in it in a school context may impact on mathematization in real life" (p. 297, my emphasis). Saying that the process of mathematization is the same, no matter what the context, does not sit well with the sociocultural perspective from which Jurdak writes. It is impossible to find support in the research reported in Jurdak's text for such statements. The belief that the exploration of real-life situations in school will impact on the way in which people use mathematics in real life is based on a "leap of faith", and thus constitutes ideology at its purest.

${ }^{8}$ As observed by Lundin $(2012$, p. 8), "[t]he faithful finds a reason why the game is played, seemingly in reality itself, and at the same time identifies a corresponding explanation why "it does not work"'. As a faithful adherent, one perceives oneself as the one "who knows, who sees the sorry state of mathematics education in the light of all that it could be, and dutifully shoulders the burden of reform". As pointed out by Lundin, however, this attitude, instead of leading to an amelioration of school mathematics, maintains the status quo. This happens because, in the wellintentioned action of improving mathematics education, the faithful fail to acknowledge, in the corrupted reality they lament, the ultimate consequences of their own acts.
} 
eliminating the obstacles, so that the higher goal of making mathematics useful for people's lives can be kept. As I noted in the former section, this is the basic definition of the Lacan-Žižek notion of ideology: a totality set on effacing the traces of its own impossibility, by displacing the internal and all-pervasive uselessness of school mathematics onto an external contingent series of events that can be overcome through better practices. Instead of assuming the impossibility of transfer (Evans, 1999; Gerofsky, 2010), research ends up by creating an ideology whose purpose is precisely to disavow such impossibility. Moreover, ideology not only conceals such impossibility, it also creates what it purports to conceal (Žižek, 2008b, p. 6). As noted by Lundin (2012) above, it is the very act of making mathematics useful for people - through the workings of mathematics education itself - that creates the impossible "ideal" of a successful relation between school and out-of-school mathematics.

\section{Between school and workplace}

I will now analyse a typical transfer situation involving workplace and school mathematics. The research reported here was initially developed by Elsa Fernandes ${ }^{9}$ in her $\mathrm{PhD}$ thesis. Hence, this particular research was already completed when I started my analysis. My purpose here is to analyse in a new light the data and the conclusions drawn them them by Elsa.

During her $\mathrm{PhD}$, Elsa collected data in a vocational school, in two different learning contexts: a mathematics classroom and a blacksmith's workshop (where students learned from a master blacksmith). She was concerned with identifying and characterizing mathematical activity that students used in practices not socially defined as mathematics and attempted to understand how that activity can be linked to the mathematics curriculum and to their development. The theoretical framework of this research was composed of Bernstein theory and situated learning theory.

The technical blacksmith course planned by the vocational school was attended by a group of youths, all boys between 16 and 21 years old, who receives the minimum Portuguese wage to attend the course. If they successfully complete it, they will receive a diploma equivalent to the ninth grade (compulsory schooling in Portugal). They have to attend different classes during the week (such as mathematics, English, technical design, computing, etc.), from nine in the morning until six at

\footnotetext{
${ }^{9}$ Elsa Fernandes participates, as does the author of this text, in the project LEARN, which is one of the activities of the Technology, Mathematics and Society Learning Research Group of the Centre for Research in Education at the University of Lisbon. One of the purposes of this project is to analyse, from a different theoretical perspective, data already collected in previous research work done by the participants in the project.
} 
night, and every alternate Friday or Saturday they have "blacksmith practice" in a real workshop. The mathematics class was designed so that the students could use the mathematical knowledge learned in class in their blacksmith practice, or, conversely, give mathematical meaning to some particular aspect of their blacksmith practice. Success in this subject was necessary for the conclusion of the course.

All participants (students, teacher and master) assume the importance of mathematics as usevalue:

However, at the end of the course, when I spoke with them [the students] again about the importance of mathematics as a part of the curriculum, all of them were peremptory in affirming that mathematics was very important. (Fernandes, 2004, p. 217)

Teacher: But a blacksmith that doesn't know how to calculate the necessary material is a false blacksmith. (p. 307)

Master: They [the students] had already told me: Well, yes! We already learned this. So, don't you know that? I knew, but I didn't know that it was here where we can use it. Didn't you know? So now you know! It comes from the school [the mathematics]. (p. 266)

A closer look makes us suspicious about whether the students actually use the mathematics they learn in school while working as blacksmiths. Elsa's remarks clearly point to the mismatch between school mathematics and the mathematics students use while performing their blacksmith work. Even though apparently we are dealing with the same knowledge, the mathematics that emerges from school practice is not recognized as being the same as that involved in the blacksmith activity, and vice versa:

When students were performing their blacksmith activity they didn't make any connections between the mathematics that they learn in this practice and the mathematics that they learn in school. (p. 296)

Apprentices learn the mathematics they use while performing the blacksmith activity, with the other more experienced blacksmiths, and I do not have any evidence that they made connections between the mathematics they learn in school and the mathematics they use as blacksmiths. (p. 368)

Alberto [One of the students] confessed that he was surprised and at the same time horrified when he saw that he would have to study mathematics in the course. However, when I asked him about the importance of mathematics in the course, he promptly answered: "mathematics is very important and it will help me a lot in this course. I think it makes sense to have mathematics in the course". (p. 203) 
One of the students, who had a lot of difficulty in learning mathematics, Alberto, said very often that it was easier to construct the object referred to in the text of the mathematical exercise presented in the classroom, than do the calculations he was asked by the teacher to do. He also said that in blacksmith practice he did not need to do such calculations; he just had to build the object. (p. 217)

Alberto was unsure about the importance of mathematics. On the one hand, while being interpellated by the researcher (whom he knew to be a mathematics teacher), he promptly stated the importance of mathematics for the blacksmith practice. During his time in the blacksmith workshop, however, he often complained about the irrelevance of school mathematics to what he was doing. Although when questioned students seemingly acknowledge the importance of mathematics for their work, when they are actually performing their work they solve problems without reference to school mathematics. The question therefore arises as to why if students show that they do not need school mathematics to perform their work as blacksmiths they say mathematics is important?

The nature of the students' engagement points towards the importance mathematics has for course completion. Despite the efforts of the teacher to make class exercises resemble blacksmith practices, what mobilizes students to learn mathematics is not the use they will make of it, but a necessity imposed by the structure of the course:

Mathematics was important because apprentices needed mathematics to obtain the course diploma. The relevance attributed by these students to mathematics did not depend on any justification intrinsic to mathematics. It depended on the role that such experience [learning mathematics] had regarding students' future options. (p. 200)

For the students, being engaged in school mathematics is not related to the mathematical activity in itself; it depends more on the predisposition of students to engage themselves in this kind of activity - that is, on the likelihood of success in the subject. The motivation for this comes from the desire of the students to become blacksmiths and, for that purpose, they have to achieve success in all the school subjects that comprise the course. (p. 365)

The engagement of students in the subject derives from a will to pass and not necessarily to learn. As a result the mechanisms put in motion by students are not aimed at learning mathematics but at learning the best strategy for success. This subsidiary promotional criterion, as Baldino and Cabral (1998) call it, "validate[s] non-learning strategies to get credit, to the benefit of those students for whom the learning-based strategy is impossible" (p. 5). In this process, the teacher is many times an accomplice to students' strategies, ending up adopting evaluation mechanisms that 
reward not the learning of mathematics but the learning of approval mechanisms. In the words of Baldino and Cabral (1998), the ideological relation between teacher and students can be described thus:

The teacher must not know that he is there to promote this passing without knowledge. Students know many things, especially they know how to pass. However what they know still better is that the teacher wants the game to go on and things to work well. They also know that the teacher does not know that this is what he wants. In order to be there, the teacher has to inebriate himself with his phantasm of minister of knowledge. (p. 5)

The way in which the teacher construes the exams, crucial for students' final grades, reveals this:

[I]n this activity [exam] students did not need to memorize the procedure because they had their notebooks at hand for consultation. Besides that, the final exam was done with their notebooks available and the tasks presented were similar to the ones students performed in class. (p. 335)

Everything seemed to be orchestrated so that students could not fail whether or not they learned any mathematics. Indeed, taking into account that this is a highly expensive course for the government (it involved learning spaces both in schools and in the workplace, students were getting paid to follow the course, many of them have a history of repeated failure in regular schooling, teachers were recruited especially to teach these students), it was not good for business to fail these people.

\section{The materialization of ideology and the real of enjoyment}

Mathematics is posited as crucial knowledge to be learned by blacksmith apprentices so that they can become skilled workers and competent citizens. The learning of mathematics is supposed to occur in a meaningful way, infiltrating "realistic" situations connected with students' blacksmith practice. At the end, there is an assessment which decides who achieved the aims and who did not. It appears, however, as if there is a set of unwritten rules which, although tacit, dictates the activity of teacher and students. For instance, it seems as if there was something preventing the teacher from failing these students. ${ }^{10}$ It is as if deep down the teacher knew that some of the students would never achieve the mathematical learning officially required, thus watering down what students need to learn by doing; for instance, exams that reproduce exercises done in class or students being allowed

\footnotetext{
${ }^{10}$ They all passed, despite the obvious difficulties some of them, e.g. Alberto, have with the subject.
} 
to use their notebooks during an exam. These unwritten rules are, according to Žižek (2008b), fundamental in maintaining a social edifice: "[o]bscene unwritten rules sustain Power as long as they remain in the shadows; the moment they are publicly recognized, the edifice of Power is thrown into disarray" (p. 93). If the official rules are to be preserved-students really have to learn mathematics, as well as to use the mathematics learned - the majority of students will fail, and their work as blacksmiths will probably become mischaracterized with the introduction of school mathematics. It is "forbidden" not only to fail these students, but also to announce this publicly. The school system needs to maintain the fiction that the teacher is allowed to fail the students and that the lack of failures simply shows that students have effectively learned important mathematics for their lives.

Instead of representing simple deviations, unwritten rules are the fundamental elements sustaining the symbolic field of a given community. Žižek (1995, p. 54) calls this the primordial lie: something must be concealed so that the community can constitute itself as a positive entity. In the case of the community of blacksmith apprentices, that which should remain "unwritten" is the unimportance of school mathematics for their work. ${ }^{11}$ When asking blacksmith apprentices if mathematics is important for their work, although we explicitly give the opportunity to students to say no, we already presuppose their affirmative answer-they are expected to say yes. If, by chance, any of them have said no ("No, mathematics is not really important, its presence in the course has just to do with its credibilization"; or even: "I am aware that I don't even have to learn mathematics, I just have to reproduce the solved exercises in the exam"), the social link between students, teacher and curriculum will be broken. Students learn that in order to become a blacksmith they have to pass a school subject called mathematics, which is actually of no use for their work. This unimportance should remain in the shadow, however; officially all the students accept the importance of mathematics for their work.

In reality, students do not have a choice regarding the presence or not of mathematics in the course. From the moment they choose to do the course, mathematics is compulsory. The attitude of the students is one of not having any choice but to "do it", despite its pointlessness. They adopt what Lundin (2012, p. 7) calls a "cynical distance", by actively distancing themselves from the activity in which they participate. For the cynical, the world, or in this case the school, is a system "created and managed by idiots, in which we have been put and to which we have to adapt" (p. 7).

\footnotetext{
${ }^{11}$ But also that in order to pass in mathematics they do not really need to learn mathematics, but only to reproduce in the exam what the teacher performed during class; they learn the correct way to answer their teacher's questions, and how to appear busy in order to avoid extra work (Fernandes, 2004).
} 
However, and this is a crucial point, the "'idiots' who 'believe in the system' and have supposedly created it accordingly, do not in fact exist" (p. 7, my emphasis).

At issue here is the "deferential" nature of belief (Žižek, 2008b): belief is never my own belief but the belief of the Other, the belief that is supposed to be believed. In our case, the belief of students in the applicability of school mathematics is not really their belief, but the belief of the "subject supposed to believe" (p. 136), which in this case is partially performed by the teacher who is supposed to believe in the importance of mathematics for blacksmith practices. Although students know that they will not use any school mathematics in their practice, they believe that mathematics is important. This belief is not corroborated by their experience, but this does not prevent it from functioning because, in order for it to function, it is only necessary to suppose that others believe. ${ }^{12}$

Who is this "Other who believes"? As pointed out by Lundin above, this "idiot" who believes has no positive existence. It is a pure fiction-a fantasy-resulting from the frenetic activity of all of those who believe in it. Although the belief that school mathematics is useful for everyday life seems to falter when we get a closer look at the activities in which people are involved outside school, it is fuelled by researchers, teachers, and, ultimately, by students themselves. There is no support in the real for the assumption that mathematics is important for the mundane activities of people. Nevertheless, this supposition persists as a powerful argument justifying the importance of school mathematics. This is the fundamental level of ideology: "not of an illusion masking the real state of things but that of an (unconscious) fantasy structuring our social reality itself” (Žižek, 2008a, p. 30). Therefore, although purely fictional, "imaginary" as Lundin (2012, p. 11) puts it, the ideology that asserts the importance of mathematics as use-value has real affects. It fuels an entire research industry, outlines school curriculums, prescribes classroom work, and is the central measure of international assessment programmes (e.g. PISA). These endeavours can be seen as the "materialization of ideology in external materiality" (Žižek, 2008b, p. 2). It is not the subjects' inner convictions - students know they will not use mathematics — but the external ritual — behaving as if mathematics is useful - that is the locus of the fantasy which sustains an ideological edifice.

Consequently, a critique of ideology seeks not so much to disclose the "ideology" corrupting our practices but to show how our practices form the necessary support for this same "ideology". Ideology has a paradoxical nature: it does not exist "out there", orchestrating our lives as if we were 12 An important distinction should be made between believing and knowing: "I believe through the other, but I cannot
know through the other" (Žižek, 2008b, p. 138). When students say they need mathematics, this assertion belongs to the
sphere of the (Lacanian) symbolic: what it really means is that students believe that others believe mathematics is
important, and the knowledge they have of the useless character of school mathematics in their practice nobody can
hold for them: they experience it in the (Lacanian) real. Our everyday ideological attitude consists precisely in the gap
between (real) knowledge and symbolic (belief). Ideology structures our belief against something we know to be real. 
marionettes, but is inherently dependent on the subjects who, while not really believing in it, keep acting as if they do. According to Žižek (1993, p. 202), this is the mode of faithfulness to ideological causes, whereby the normal order of causality is inverted, since "it is the Cause itself which is produced by its effects (the ideological practices it animates)". The Other who believes in the use-value of mathematics is not an effect of the importance mathematics has in the material world but is what causes this belief.

This is the reason why the old ideology critique based on the disclosure of a "false consciousness" is not enough: "one can know what one is doing and still go ahead and do it" (Žižek, 2012, p. 983). People today know about the falsity of the ideological discourse. Researchers know that students do not use school mathematics outside school. They know that school mathematics serves other purposes than the ones preached by research and governments in terms of knowledge and competences. We cannot say that people are naive beings, whose minds are dominated by a false consciousness that needs to be deconstructed. When researchers know that people do not transfer mathematics from and into school, and still insist on the importance of mathematics as use-value, they are performing what Žižek (2008b) calls a fetishistic disavowal: one knows, but one does not really believe what one knows, and thus keeps acting as if one does not know. The attachment to a Cause (Žižek, 1993, p. 202) - in our case, the naturalization of the importance of mathematics in terms of mathematics itself - cannot be reduced to a performative effect of the discursive practices that refer to it. As posited by Žižek (1993):

The pure discursive effect does not have enough "substance" to compel the attraction proper to a Cause - and the Lacanian term for the strange "substance" which must be added so that a Cause obtains its positive ontological consistency, the only substance acknowledged by psychoanalysis is of course enjoyment. (p. 202)

What secures a given ideological edifice, what binds us to explicit ideologies, is not so much a rational decision but a mode of enjoyment. The crucial question about ideology is thus not to be posited in terms of knowledge — what people need to know in order to break the ideological spellbut in terms of enjoyment: what do people enjoy that prevents them from changing? The attachment to something we know is "wrong" can only be explained in terms of enjoyment: after the ideology has been exposed we still do not change our behaviour because we enjoy it. That being so, breaking the ideological spell is not just a matter of knowing the ideological mechanisms that constrain us, but, on a more fundamental level — that is, an unconscious level—, to traverse the fantasy (Lacan, 
2007) mapping the relation of the subject with the kernel of its jouissance. Something has to change not just at a rational level-knowing the useless character of mathematics, for instance — but also at the level of enjoyment.

What do researchers and students enjoy that keeps them attached to the belief that mathematics is important for their daily lives? Or, in a broader sense, what do they enjoy that keeps them attached to the belief that mathematics is important in itself? In the case of the community of "blacksmith apprentices", students know the falsehood of school mathematics very well, they can even be aware of a particular interest - the credibilization of the course through the insertion of mathematics, for instance-hidden behind an ideological universality - the importance of mathematics for their work - but still they do not renounce it. Renunciation implies tearing apart the universality sustaining the professional course. Nobody has any interest in that, especially not students, who see in this course an opportunity to finish compulsory education. As I observed before, what students enjoy is not mathematics itself, but what circulates in the Other as school credit (and, in the particular case of the blacksmith apprentices, a concrete wage). In the case of researchers, we cannot be blind to the fact that there are obvious benefits from the belief that mathematics is precious knowledge, a keystone of modern society, and an inescapable tool for citizenship. This makes mathematics education a privileged area of research among educational sciences, with all the concomitant benefits of funding, working conditions and possibilities for research. To assume that school mathematics is more about credit than about mathematics itself implies questioning the entire discourse sustaining mathematics education research, thus jeopardizing the central role mathematics has in education, with all the consequences this will have for our work. We can risk saying that what researchers enjoy is university credit, an expression more and more in tune with the current functioning of academic life, where terms such as "knowledge production", "quotations index" and "number of publications" dictate the overriding goals of a whole swathe of social, cultural and intellectual activities previously understood and valued in other terms.

\section{Final remarks}

Albeit mathematics may not be very useful as a mean to understand the world around us, the discourse on its importance contributes fundamentally to the exceptional utility this science has within a school's credit system. The more importance is given to mathematics in terms of intelligence, self-confidence, mastering the world, democracy and the like, the more this science is 
important as an economic instrument of social selection. Ideology produces its effect through its own failure so that, in the end, "one does actually meet mathematics every day and we do need mathematical knowledge to solve problems of this everyday life" (Lundin, 2012, p. 11). Yet that sort of mathematics and these problems are far from those desired by researchers. The mathematics is that needed to pass an exam, and the problems are those inherent in a society where access to privilege is justified by success in a meritocratic system.

However uncomfortable it may be, schools are places of social selection and teachers are agents of exclusion - they are asked, year after year, to mark students with a grade that will determine (sometimes significantly) their future options. Apparently, there is no way of avoiding such accreditation system, and mathematics education research ends up taking it for granted. Research then develops as if it were possible, through the betterment of research and the amelioration of classroom practices, to achieve the desired equity. If, however, failure is a necessary condition of today's schooling it follows that it cannot be eradicated. My suggestion is that research should investigate school mathematics as a crucial element in this accreditation system, rather than as precious knowledge intended to empower people and to enable societal development.

The question of how to do it is an open one. It may well imply a complete redefinition of the way in which mathematics education is perceived by those who work in it, but this is the precise purpose of a sociopolitical approach to mathematics education (Gutiérrez, 2010, p. 20; Sriraman \& English, 2010, p. 25). My only caveat regarding this approach concerns the way in which it disavows the possibility of taking school mathematics in its totality - that is, as involving both the ideal of "mathematics for all" and its ultimate failure. As I previously observed, the domain of the multitude of particular "struggles" characteristic of the sociopolitical turn is sustained by the repression of the role mathematics plays within capitalist schooling, where failure is a necessity. The reason why I find the concept of ideology so captivating is precisely because it allows me to address the incongruities between the official discourse and its actualization within a life world context - in this case, schools. As we have seen, that which at the level of the official discourse runs smoothly - the argument of the utility of mathematics for becoming a worker or a citizen is well established - when actualized in a specific practice encounters a series of obstacles which ends up perverting the official intention. Usually research proceeds by eliminating such obstacles, so that the official aims can be fully actualized. An ideology critique is however interested in analysing these obstacles since they stand for the symptomatic points which allow one to grasp the political 
and economic relevance of school mathematics. My suggestion is that research should bring these obstacles - what I have called the unwritten rules - within its purview and investigate them not as correctable deviations from the official rule, but as fundamental conditions of today's schooling.

\section{Acknowledgements}

This article is part of my $\mathrm{PhD}$ project, supported by the Foundation for Science and Technology of Portugal, grant SFRH/BD/38231/2007. It is also part of the Project LEARN, funded by the same foundation (contract PTDC/CED/65800/2006).

\section{References}

Abreu, G. (1995). Understanding how children experience the relationship between home and school mathematics. Mind, Culture and Activity, 2, 119-142.

Abreu, G., Bishop, A., \& Presmeg, N. (2002). Transitions between contexts of mathematical practices. Dordrecht: Kluwer.

Althusser, L. (1994). Ideology and ideological state apparatuses (notes towards an investigation). In S. Žižek (Ed.), Mapping ideology (pp. 100-140). New York and London: Verso.

Atweh, B., Forgasz, H., \& Nebres. (Eds.) (2001). Sociocultural research on mathematics education: An international perspective. Mahwah, NJ: Lawrence Erlbaum.

Atweh, B., Graven, M., Secada, W., \& Valero, P. (Eds.) (2011). Mapping equity and quality in mathematics education. New York: Springer.

Baldino, R. (1998a). Assimilação solidária: Escola, mais-valia e consciência cínica [Solidarity assimilation: School, surplus-value and cynical consciousness]. Educação em Foco, 3(1), 39-65.

Baldino, R. (1998b). School and surplus-value: Contribution from a third-world country. In P. Gates (Ed.), Proceedings of the First International Conference on Mathematics Education and Society (MES1) (pp. 73-81). Nottingham: Centre for the Study of Mathematics Education.

Baldino, R., \& Cabral, T. (1998). Lacan and the school's credit system. In A. Olivier \& K. Newstead (Eds.), Proceedings of 22nd Conference of the International Group for the Psychology of Mathematics Education (PME22) (Vol. 2, pp. 56-63). Stellenbosch, South Africa: University of Stellenbosch.

Baldino, R., \& Cabral, T. (1999). Lacan's four discourses and mathematics education. In O. Zaslavsky (Ed.), Proceedings of the 23rd International Conference of the Psychology of Mathematics Education Group (PME23) (Vol. 2, pp. 57-64). Haifa, Israel: Technion Israel Institute of Technology.

Baldino, R., \& Cabral, T. (2006). Inclusion and diversity from Hegel-Lacan point of view: Do we desire our desire for change? International Journal of Science and Mathematics Education, 4, $19-43$. 
Bishop, A., \& Forgasz, H. (2007). Issues in access and equity in mathematics education. In F. Lester (Ed.), Second handbook of research on mathematics teaching and learning (pp. 11451168). Charlotte, NC: Information Age.

Blum, W., \& Niss, M. (1991). Applied mathematical problem solving, modelling, applications, and links to other subjects - state, trends and issues in mathematics instruction. Educational Studies in Mathematics, 22(1), 37-68.

Boaler, J. (1993). Encouraging the transfer of 'school' mathematics to the 'real world' through the integration of process and content, context and culture. Educational Studies in Mathematics, 25, 341-373.

Boaler, J. (1999). Participation, knowledge and beliefs: A community perspective on mathematics learning. Educational Studies in Mathematics, 40(3), 259-281.

Boaler, J. (2009). The elephant in the classroom: Helping children learn and love maths. London: Souvenir Press.

Brenner, M. (1998). Meaning and money. Educational Studies in Mathematics, 36, 123-155.

Brown, T. (2008). Lacan, subjectivity, and the task of mathematics education research. Educational Studies in Mathematics, 68(3), 227-245.

Brown, T. (2011). Mathematics education and subjectivity: Cultures and cultural renewal. Dordrecht: Springer.

Brown, T., \& McNamara, O. (2011). Becoming a mathematics teacher: Identity and identifications. Dordrecht: Springer.

Brown, T., \& Walshaw, M. (2012). Mathematics education and contemporary theory: Guest editorial. Educational Studies in Mathematics, 80(1-2), 1-8.

Brown, W. (1995). States of injury. Princeton, NJ: Princeton University Press.

Butler, J. (1997). The psychic life of power. Stanford, CA: Stanford University Press.

Butler, J., Laclau, E., \& Žižek, S. (2000). Contingency, hegemony, universality. London: Verso.

Chapman, O. (2006). Classroom practices for context of mathematics word problems. Educational Studies in Mathematics, 62(2), 211-230.

Cole, M. (2003). Might it be in practice that it fails to succeed? A Marxist critique of claims for postmodernism and poststructuralist as forces for social change and social justice. British Journal of Sociology of Education, 24(4), 487-500.

De Lange, J. (1996). Using and applying mathematics in education. In A. Bishop, M. Clements, C. Keitel, J. Kilpatrick, \& C. Laborde (Eds.), International handbook of mathematics education (pp. 49-97). Dordrecht: Kluwer.

Derrida, J. (1976). Of grammatology. Baltimore, MD: The Johns Hopkins University Press.

Dowling, P. (1998). The sociology of mathematics education: Mathematical myths, pedagogic texts. London: Falmer.

Eagleton, T. (2001). Ideology, discourse, and the problems of 'post-marxism'. In S. Malpas (Ed.), Postmodern debates (pp. 79-92). Basingstoke, UK: Palgrave.

Engels, F. (1968). Marx and Engels Correspondence (Letter to Franz Mehring, London, July 14, 1863). International Publishers. Retrieved from http://www.marxists.org/archive/marx/works/1893/letters/93 07 14.htm, 25 December 2012. 
Ernest, P. (2007). Epistemological issues in the internationalization and globalization of mathematics education. In B. Atweh, A. Calabrese, B. Barton, M. Borba, N. Gough, C. Keitel, C. Vistro-Yu, \& R. Vithal (Eds.), Internationalisation and globalisation in mathematics and science education (pp. 19-38). New York: Springer.

Evans, J. (1999). Building bridges: Reflections on the problem of transfer of learning in mathematics. Educational Studies in Mathematics, 39, 23-44.

Fernandes, E. (2004) Aprender matemática para viver e trabalhar no nosso mundo [Learning mathematics to live and work in our world]. $\mathrm{PhD}$ thesis. University of Lisbon.

Fernandes, E. (2008). Rethinking success and failure in mathematics learning: The role of participation. In J.F. Matos, P. Valero, \& K. Yasukawa (Eds.), Proceedings of the Fifth International Mathematics and Society Conference [MES5](pp. 237-247). Lisbon: Centro de Investigação em Educação, Universidade de Lisboa.

Fink, B. (1995). The Lacanian subject: Between language and jouissance. Princeton, NJ: Princeton University Press.

Frankenstein, M. (1983). Critical mathematics education: An application of Paulo Freire's epistemology. Journal of Education, 165(4), 315-339.

Freudenthal, H. (1973) Mathematics as an educational task. Dordrecht: Reidel.

Gerofsky, S. (2010). The impossibility of 'real-life' word problems (according to Bakhtin, Lacan, Žižek and Baudrillard). Discourse: Studies in the Cultural Politics of Education, 31(1), 61-73.

Gravemeijer, K. (1994). Developing realistic mathematics education. Utrecht: CDbeta.

Gutiérrez, R. (2010). The sociopolitical turn in mathematics education. Journal for Research in Mathematics Education, 41(0), 1-32.

Hoyles, C., Noss, R., Kent, P., \& Baker, A. (2010). Improving mathematics at work. New York: Routledge.

Hudson, B. (2008). Learning mathematically as social practice in a workplace setting. In A. Watson \& P. Winbourne (Eds.), New directions for situated cognition in mathematics education (pp. 287-302). New York: Springer.

Jameson, F. (1991). Postmodernism or, the cultural logic of late capitalism. Durham, NC: Duke University Press.

Jurdak, M. (2006). Contrasting perspectives and performance of high school students on problem solving in real world situated and school contexts. Educational Studies in Mathematics, 63, 283301.

Klette, K. (2004). Classroom business as usual? (What) do policymakers and researchers learn from classroom research? In M. Høine \& A. Fuglestad (Eds.) Proceedings of the 28th Conference of the International Group for the Psychology of Mathematics Education [PME28], (Vol. 1, pp. 316). Bergen, Norway.

Lacan, J. (2007). The other side of psychoanalysis: The seminar of Jacques Lacan book XVII [1st ed. 1991]. New York: Norton \& Company.

Lave, J. (1988). Cognition in practice: Mind, mathematics, and culture in everyday life. Cambridge: Cambridge University Press.

Lave, J., \& McDermott, R. (2002). Estranged learning. Outlines, 1, 19-48. 
Lerman, S. (2000). The social turn in mathematics education research. In J. Boaler (Ed.), Multiple perspectives on mathematics teaching and learning (pp. 19-44). Westport, USA: Ablex.

Lundin, S. (2012). Hating school, loving mathematics: On the ideological function of critique and reform in mathematics education. Educational Studies in Mathematics, 80(1), 73-85.

Lyotard, J.-F. (1984). The postmodern condition: A report on knowledge [1st ed. 1979]. Minneapolis: University of Minnesota Press.

Martin, D. B. (2011). What does quality mean in the context of white institutional space? In B. Atweh, M. Graven, W. Secada, \& P. Valero (Eds.), Mapping equity and quality in mathematics education (pp. 437-450). New York: Springer.

NCTM. (2000). Principles and standards for school mathematics. Reston: NCTM.

Niss, M. (2007). Reflections in the state and trends in research on mathematics teaching and learning: From here to utopia. In F. Lester (Ed.), Second handbook of research on mathematics teaching and learning (pp. 1293-1312). Charlotte, NC: Information Age Publishing.

Niss, M., Blum, W., \& Huntley, I. (Eds.) (1991). Teaching of mathematical modelling and applications. Chichester: Ellis Horwood.

Nunes, T., Schliemann, A., \& Carraher, D. (1993). Street mathematics and school mathematics. New York: Cambridge University Press.

OECD (1999). Measuring student knowledge and skills: A new framework for assessment. Paris: OECD.

Ozselçuk, C., \& Madra, Y. (2010). Enjoyment as an economic factor: Reading Marx with Lacan. Subjectivity, 3(3), 323-347.

Pais, A. (2011a). Criticisms and contradictions of ethnomathematics. Educational Studies in Mathematics, 76(2), 209-230.

Pais, A. (2011b). Mathematics education and the political: An ideology critique of an educational research field. PhD Thesis. Denmark: Aalborg University.

Pais, A. (2012). A critical approach to equity in mathematics education. In O. Skovsmose \& B. Greer (Eds.), Opening the cage: Critique and politics of mathematics education (pp. 49-92). Rotterdam: Sense Publishers.

Pais, A., Fernandes, E., Matos, J., \& Alves, A. (2012). Recovering the meaning of "critique" in critical mathematics education. For the Learning of Mathematics, 32(1), 29-34.

Pais, A., \& Valero, P. (2012). Researching research: Mathematics education in the political. Educational Studies in Mathematics, 80(1-2), 9-24.

Peters, A., \& Burbules, N. (2004). Poststructuralist and educational research. Lanham, MD: Lowman and Littlefield.

Popkewitz, T. S. (2004). The alchemy of the mathematics curriculum: Inscriptions and the fabrication of the child. American Educational Research Journal, 41(1), 3-34.

Presmeg, N. (2010). Editorial. Educational Studies in Mathematics, 73(1), 1-2.

Radford, L. (2012). Education and the illusions of emancipation. Educational Studies in Mathematics, 80(1-2), 101-118.

Riall, R., \& Burghes, D. (2000). Mathematical needs of young employees. Teaching Mathematics and its Applications, 19 (3), 104-113.

Saxe, G. (1991). Culture and cognitive development. Mahwah, NJ: Erlbaum. 
Secada, W., Fennema, E., \& Byrd, L. (Eds.). (1995). New directions for equity in mathematics education. Cambridge: Cambridge University Press.

Seidman, S. (Ed.) (1994). The postmodern turn: New perspectives on social theory. Cambridge: Cambridge University Press.

Sierpinska, A., \& Kilpatrick, J. (Eds.) (1998). Mathematics education as a research domain: A search for identity. Dordrecht: Kluwer.

Skovsmose, O. (1994). Towards a philosophy of critical mathematics education. Dordrecht: Kluwer.

Sriraman, B., \& English, L. (2010). Surveying theories and philosophies of mathematics education. In B. Sriraman \& L. English (Eds.), Theories of mathematics education: Seeking new frontiers (pp. 7-32). Heidelberg, DL: Springer.

Sriraman, B., Roscoe, M., \& English, L. (2010). Politicizing mathematics education: Has politics gone too far? Or not far enough? In B. Sriraman \& L. English (Eds.), Theories of mathematics education: Seeking new frontiers (pp. 621-638). Heidelberg: Springer.

Stech, S. (2008). School mathematics as a developmental activity. In A. Watson \& P. Winbourne (Eds.), New directions for situated cognition in mathematics education (pp. 13-30). New York: Springer.

Stinson, D. (2004). Mathematics as "gate-keeper"(?): Three theoretical perspectives that aim toward empowering all children with a key to the gate. The Mathematics Educator, 14(1), 8-18.

Valero, P. (2004). Socio-political perspectives on mathematics education. In P. Valero \& R. Zevenbergen (Eds.), Researching the socio-political dimensions of mathematics education (pp. 5-24). Boston: Kluwer.

Valero, P., \& Stentoft, D. (2010). The 'post' move of critical mathematics education. In H. Alrø, O. Ravn \& P. Valero (Eds.), Critical mathematics education: Past, present and future (pp. 183196). Rotterdam: Sense Publishers.

Verschaffel, L., Greer, B., \& De Corte, E. (2000). Making sense of word problems. Lisse: Swets \& Zeitlinger.

Verschaffel, L., Greer, B., Van Dooren, W., \& S. Mukhopadhyay (2009). Words and worlds: Modelling verbal descriptions of situations. Rotterdam: Sense Publishers.

Vighi, F., \& Feldner, H. (2007). Ideology or discourse analysis? Žižek against Foucault. European Journal of Political Theory, 6(1), 141-159.

Vinner, S. (1997). From intuition to inhibition-mathematics education and other endangered species. In E. Pehkonen (Ed.), Proceedings of the 21th conference of the International Group for Psychology of Mathematics Education (Vol. 1, pp. 63-78). Helsinki: Lahti Research and Training Centre, University of Helsinki.

Vinner, S. (2000). Mathematics education: Procedures, rituals and man's search for meaning. Regular lecture given at the Ninth International Congress of Mathematics Education (ICME9), Japan. Retrieved from http://www.fi.uu.nl/nwd/nwd2003/handouts/vinner.pdf, 20 February 20012.

Walshaw, M. (2004). The pedagogical relation in postmodern times: Learning with Lacan. In M. Walshaw (Ed.), Mathematics education within the postmodern (pp. 121-140). Charlotte, NC: Information Age Publishing. 
Williams, J. (2011). Towards a political economic theory of education: Use and exchange values of enhanced labor and power. Mind, Culture and Society, 18, 276-292.

Williams, J., \& Wake, G. (2007). Black boxes in workplace mathematics. Educational Studies in Mathematics, 64, 317-343.

Žižek, S. (1993). Tarrying with the negative. Durham: Duke University Press.

Žižek, S. (1994). The spectre of ideology. In S. Žižek (Ed.), Mapping ideology (pp. 1-33). London and New York: Verso.

Žižek, S. (1995). The metastases of enjoyment. London: Verso.

Žižek, S. (2004). Organs without bodies: Deleuze and consequences. London: Routledge.

Žižek, S. (2008a). The sublime object of ideology [1st ed. 1989]. London: Verso.

Žižek, S. (2008b). The plague of fantasies [1st ed. 1997]. London: Verso.

Žižek, S. (2012). Less than nothing. London: Verso. 